\title{
REACTOR OPERATIONS
}

\author{
BROOKHAVEN MEDICAL RESEARCH REACTOR \\ BROOKHAVEN HIGH FLUX BEAM REACTOR
}

\author{
H. M. Hauptman, Group Leader, Medical Reactor \\ J. N. Petro, Group Leader, Instrumentation \\ O. Jacobi, Group Leader, Maintenance \\ V. Lettier, Group Leader, Cold Neutron Facility \\ N. Holden, Research Coordinator \\ D. Ports, Group Leader, Operations \\ R. Petricek, Group Leader, Compliance
}

Approved: Lance L. Junker, Manager, Reactor Division

SEPTEMBER 1994

INFORMAL REPORT

BROOKHAVEN NATIONAL LABORATOR Y

AS S OCIATED UNIVERSITIES, INC.

U P T O N, NEW Y OR K 11973-5000

under contract No. DE-AC02-76CH00016 with the

United States Department of Energy

\section{DISCLAIMER}

This report was prepared as an account of work sponsored by an agency of the United States Government. Neither the United States Government nor any agency thereof, nor any of their employees, makes any warranty, express or implied, or assumes any legal liability or responsibility for the accuracy, completeness, or usefulness of any information, apparatus, product, or process disclosed, or represents that its use would not infringe privately owned rights. Reference herein to any specific commercial product, process, or service by trade name, trademark, manufacturer, or otherwise does not necessarily constitute or imply its endorsement, recommendation, or favoring by the United States Government or any agency thereof. The views and opinions of authors expressed herein do not necessarily state or reflect those of the United States Government or any agency thereof. 


\section{DISCLAIMER}

Portions of this document may be illegible in electronic image products. Images are produced from the best available original document. 


\section{Part I}

\section{Brookhaven Medical Research Reactor}

\section{1. $\quad$ Reactor}

The reactor ran for 18 days with 28 startups during the month of September. A total of 135.93 Mwhrs of thermal energy were produced bringing the total to date to 21,234.94 Mwhrs.

2. Instrumentation

There were no reportable events during the month of September, 1994.

3. Mechanical Maintenance

All tickler card maintenance was completed.

4. Occurrence Reports

There were no reportable occurrences at the BMRR for the month of September, 1994.

5. Safety

There were no reportable first aid cases at the reactor for the month of September, 1994. 
MONFH September YEAR 1994

\section{Requirement}

\section{Operations}

Confinement system

a. Nuclear Incident System $(M-4.2 .4)$

b. Bldg. Relief Valves $(M-4.2 .2)$

c. Reactivity Limitation $(A-4.3 .1)$

\section{Instrumentation}

a. Release Time Rod Holding Magnets $(A-4 \cdot 3 \cdot 7)$

b. Control Rod Drop Times (Q-4.3.4)

c. Control Rod Worths $(A-4.3 .2)$

d. Control Rod Withdrawal speed $(A-4.3 .3)$

e. Response Time AC Power Loss (A-4.3.8)

f. Radiation Monitors Calibration

\section{Previous}

Completion

Date

M

$M$

A

A

$\mathbf{Q}$

A

A

A

A

Period

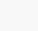

$08 / 18 / 94$

$09 / 01 / 94$

$09 / 20 / 93$

$09 / 13 / 93$

$07 / 20 / 94$

$09 / 20 / 93$

$09 / 13 / 93$

$11 / 08 / 93$

$08 / 26 / 93$
Completion

pate

$09 / 94$

$09 / 94$

$09 / 94$

$09 / 94$

$09 / 21 / 94$

15/94

$09 / 26 / 94$

$09 / 94$

$09 / 27 / 94$

$09 / 94$

$09 / 27 / 94$

$09 / 21 / 94$

$09 / 21 / 94$

$10 / 10 / 94$

[TSSRR/septechs]

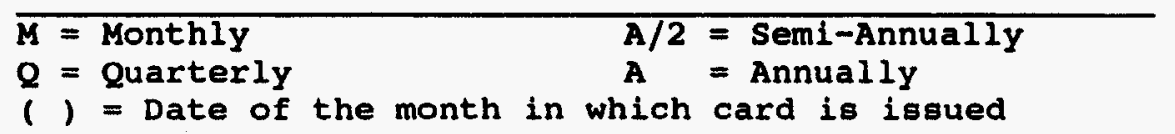




\begin{tabular}{|c|c|c|c|c|}
\hline DATE & PROJECT & HOURS & FACILITY & DESCRIPTION OF SAMPLE \\
\hline $09 / 01 / 94$ & DAT & 3.250 & $\overline{P n-T U B E}$ & SiO2 SLIDES \\
\hline $09 / 01 / 94$ & MEDICAL & 5.500 & RADIAL & CELLS w/B-10 \\
\hline $09 / 02 / 94$ & REACTOR & 1.833 & ANIMAL & BNCT TREATMENT EQMT \\
\hline $09 / 06 / 94$ & MEDICAL & 1.550 & PATIENT & CELLS \\
\hline $09 / 06 / 94$ & MEDICAL & 1.167 & PATIENT & CELLS IN GdCl3 \\
\hline 09/07/94 & MEDICAL & 6.717 & PATIENT & RATS \\
\hline 09/08/94 & MEDICAL & 6.883 & PATIENT & RATS \\
\hline 09/08/94 & DAT & 0.267 & Pn-TUBE & $\operatorname{Th}(\mathrm{NO} 3) 4$ (Th-232) \\
\hline 09/09/94 & MEDICAL & 6.917 & PATIENT & RATS \\
\hline $09 / 13 / 94$ & MEDICAL & 0.617 & RADIAL & BPA (B-10) SOLUTION \\
\hline $09 / 13 / 94$ & MEDICAL & 0.167 & ANIMAL & FLUX MEASUREMENTS \\
\hline $09 / 13 / 94$ & MEDICAL & 0.133 & Pn-TUBE & In-115 STDS \\
\hline $09 / 13 / 94$ & MEDICAL & 2.500 & PATIENT & RATS \\
\hline $09 / 13 / 94$ & MEDICAL & 1.050 & ANIMAL & BNCT PATIENT (FEM) \\
\hline $09 / 14 / 94$ & MEDICAL & 2.000 & PATIENT & CELLS \\
\hline $09 / 15 / 94$ & MEDICAL & 6.450 & PATIENT & RATS \\
\hline $09 / 16 / 94$ & MEDICAL & 6.000 & PATIENT & RATS \\
\hline $09 / 20 / 94$ & MEDICAL & 6.333 & RADIAL & CELLS w/B-10 \\
\hline $09 / 20 / 94$ & DAT & 3.450 & Pn-TUBE & SiO2 SLIDES \\
\hline $09 / 22 / 94$ & CHEMISTRY & 0.333 & Pn-TUBE & LIMESTONE \\
\hline $09 / 22 / 94$ & MEDICAL & 0.167 & Pn-TUBE & GdCl3 (Gd-158) \\
\hline $09 / 22 / 94$ & MEDICAL & 2.500 & PATIENT & RATS \\
\hline $09 / 23 / 94$ & MEDICAL & 1.167 & PATIENT & CELLS \\
\hline $09 / 27 / 94$ & MEDICAL & 1.383 & PATIENT & CELLS \\
\hline 09/29/94 & MEDICAL & 6.633 & RADIAL & CELLS w/B-10 \\
\hline $09 / 29 / 94$ & S\&EP & 0.375 & Pn-TUBE & $\mathrm{I}-127$ \\
\hline $09 / 29 / 94$ & DAT & 3.750 & Pn-TUBE & SiO2 SLIDES \\
\hline $09 / 30 / 94$ & MEDICAL & 6.567 & RADIAL & CELLS w/B-10 \\
\hline
\end{tabular}

TOTAL NO. OF HOURS $=86$

TOTAL NO. OF SAMPLE CAPSULES LOADED $=8$ 


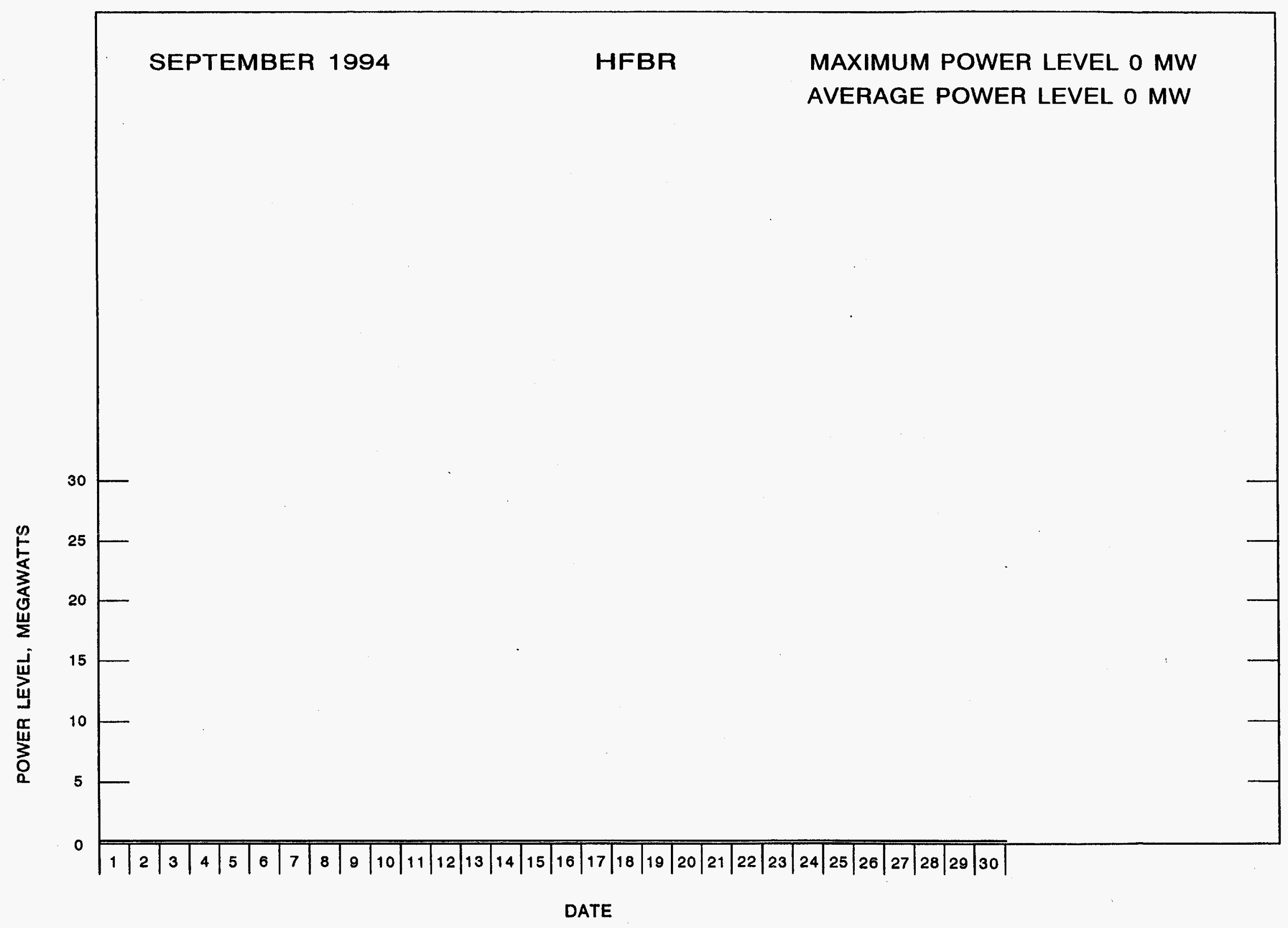


PART II

\title{
Brookhaven High Flux Beam Reactor
}

\author{
September \\ 30 Days \\ $10534-10563$
}

Reactor Operation to Date

$272,228.63 \quad$ MWD

Reactor Operation for Month

$0.00 \quad$ MWD

Hours of Operation

$0.00 \quad$ HRS

Average Power Level ((MWDx24) / Hours of Operation)

$0.00 \quad$ MW

Maximum Power Level

$0.00 \quad \mathrm{MW}$

Downtime

Electrical Energy Consumed within HFBR Bldg.

438,000

KWH

Electrical Energy Consumed by Sec. Water Pumps

4,400 .

KWH

Electrical Energy Consumed in Pumphouse $440 \mathrm{~V}$ System

2,200

$\mathrm{KWH}$

Total Electrical Energy Consumed within HFBR Complex

Electrical Energy Consumed by CNF Compressor

444,600 .

KWH

60,000

$\mathrm{KWH}$

Elements Charged this Month

0

Elements Discharged this Month

0

Reactor $\mathrm{D}_{2}$ O Inventory (within 200 pounds)

$103,491.00$

$(46,943.51$

LBS

$\mathrm{KG)}$

Reactor $\mathrm{D}_{2}$ O Isotopic Purity (Average All Systems)

$$
99.53 \%
$$

Helium Consumed (NTP)

14,300

$\mathrm{CF}$

1404 .

$\mathrm{CO} 2$ Consumed

5,000 .

LBS

$(2,268$.

$\mathrm{KG)}$ 


\section{Explanation of Histogram}

The reactor was not operated during the month of September. The reactor has been shutdown since August 18, 1994 for scheduled maintenance, refueling and continuation of the investigation of elevated tritium levels in the $\mathrm{CO}_{2}$ cavity. Based upon the final results of all the inspections, test procedures and evaluations it was concluded that these elevated tritium levels was caused by a water $\left(D_{2} O\right)$ spill in the reactor pit during repair of emergency level indicator, LI109 (see January and February monthly reports). Further details may be found in Occurrence Report CH-BH-BNL-HFBR-1994-0009.

\section{Qperating Difficulties}

On September 7, 1994 in preparation for a five year battery test by the Reactor Instrument Group, there was a momentary interruption of 24 VDC power, as a lug was lifted from the battery post to connect a test cable causing an unplanned trip of the Nuclear Incident Alarm System (NIAS). The test was terminated and the NIAS system was reset after restoring building ventilation to normal. This event was categorized as an unusual occurrence and further details may be found in Occurrence Report CH-BH-BNL-HFBR-1994-0010.

On September 14, 1994 at approximately 1200 hours, during fuel discharging operations, a spent fuel element suspended over the reactor was inadvertently dropped back into the reactor vessel. The fuel element, which came to rest on the transition plate, appeared undamaged. Visual inspection of the top of the reactor core and other vessel components also revealed no damage. The dropped element was returned to its core position and fuel discharging operations were suspended. This event was categorized as an unusual occurrence and further details may be found in Occurrence Report CH-BH-BNL-HFBR-1994-0011.

On September 23, 1994 at approximately 0130 hours Operations personnel reported a small water leak on the equipment level. The leak was from outside rain water leaking through the concrete wall on the equipment level. A confinement test as described later in this report confirmed that the hairline crack was insignificant and repairs could be delayed and scheduled for a future shutdown.

On September 26, 1994 at 2210 hours the control room received a leak detector alarm from the HFBR equipment level. An operator responded to the equipment level and noted a strong acrid smell and immediately left the area. The shift supervisor ordered a precautionary evacuation of the HFBR Facility (Building 750). Monitoring of the control room instrumentation was established at the South Lobby. A fire/rescue team and a reactor operator were dispatched to the equipment level wearing SCBA to sample for atmospheric chemical contaminants. A pipe break in the building air conditioning secondary cooling water system was found and isolated by the Operator. The cause of the chemical odor was a bromine/chlorine compound used to chemically treat the water. The control room was remanned on September 27 at approximately 0400 hours and access to the equipment level was restricted as plans were 
made to for reentry and cleanup. Normal access to the equipment level was restored on September 30, 1994. This event was categorized as an unusual occurrence and further details may be found in Occurrence Report CH-BH-BNL-HFBR-1994-0012.

\section{Reactivity Comments}

None.

\section{Buildine Confinement Test and Changes}

A surveillance test was performed on September 25, 1994 to satisfy the Building Confinement Leak Rate Technical Safety Requirements. Calculations performed at the completion of a 12 hour, 1 psi confinement leak rate test indicated a leak rate of $4.85 \pm .11 \%$ per day which meets the TSR upper limit of $6.2 \%$ per day.

Building confinement was considered broken since the September 26, 1994 chemical release reported above, due to possible degradation of the Exit Air Bypass Filter Facility. On September 28, 1994 a collection efficiency test was performed on the HEPA filters. The resulting efficiency of the test was $99.979 \%$. On September 29, 1994 an iodine absorption test of the charcoal filters was performed. The results of this test were unsatisfactory but were within one percent of passing. The test was rescheduled for October 3, to allow at least 3 days of normal air flow through the filters to remove absorbed contaminants.

\section{Changes to Reactor or Process Systems}

The Gamewell transmitters used to transmit the NIAS and fire alarm signals from the HFBR to the Fire and Security Group were replaced. The NIAS alarm is now transmitted to Security via the Moseler System. Both fire and NIAS alarm are transmitted to the firehouse via the Wormald Site Fire Alarm System, through the Data Gathering Panel in the HFBR lobby. Installation by the Site Fire Alarm Group and testing by Operations personnel was completed satisfactorily on September 21, 1994.

\section{Instrumentation}

During routine testing of the 24 VDC Battery Bank, the constant loads connected to the battery were deenergized. The test was terminated and an occurrence report generated. Details of this event are in UOR CH-BH-BNL-HFBR-1994-0010.

\section{Mechanical Maintenance}

All scheduled tickler card maintenance was performed. 


\section{Occurrence Reports}

There were three reportable occurrences at the HFBR during the month of September, 1994.

CH-BH-BNL-HFBR-1994-0010, Unplanned Trip of Nuclear Incident Alarm System (NIAS) During Maintenance Testing - 9/7/94.

CH-BH-BNL-HFBR-1994-0011, Dropped HFBR Spent Fuel Element During Fuel Discharging Operation - 9/14/94.

CH-BH-BNL-HFBR-1994-0012, Precautionary Evacuation of Building 750 Due to Chemical Odor - 9/26/94.

10. Experimental Facilities

The reactor was shutdown for the month of September, 1994. There was no experimental work being performed.

11. Cold Neutron Facility

Operating History

The CNF was shutdown for the entire month of September, 1994.

Operating Difficulties

None.

\section{Maintenance Activities}

All required maintenance and surveillance testing was completed. Started installation of new helium refrigerator temperature diodes and indicator, MRA \#94-13.

12. Safety

There were four reportable first aid cases for the month of September, 1994. 
13. Euel Element Inventory

Elements in Use as of September 30, 1994

In Reactor(s)

HFBR $28 \quad$ BMRR 35

63

Element Movement during the Month

Charged to reactor

0

Discharged from reactor

0 
September 1994.

Requirement

AA $2.1 . \exp$ Chloride content in Experimental system BIMONTHLY

AA 2.1.pri

Chloride content in Primary system

BIMONTHLY

IR 2 . exp

Isotopic Purity of Experimental system WEEKLY

IR 2.pri

Isotopic Purity of

WEEKLY Primary System

MIS 1.1

Determination of $p D$ with Orion $\mathrm{pH}$ meter (Primary System)

WEEKLY

TC 302

Criticality Alarm

System Operability Test

MONTHLY

TC 310

SPAM Station Checks

MONTHLY

TC $116 \mathrm{E}$

Nuclear Instrumentation

Performance

$\mathrm{JAN} / \mathrm{APR} / \mathrm{JUL} / \mathrm{OCT}$

TC 116F

LOLOLOW AND LOLOW LOgIC

Action \& Channel

Independency

$\mathrm{JAN} / \mathrm{APR} / \mathrm{JUL} / \mathrm{OCT}$
Previous

Tech Spec

Period

M

M

M

M

M

M

M

$3 \mathrm{M}$

OVERDUE

$3 \mathrm{M}$ Date

$09 / 19 / 94$

$09 / 19 / 94$

$09 / 19 / 94$

$09 / 19 / 94$

$09 / 19 / 94$

$08 / 01 / 94$

$08 / 15 / 94$

$03 / 24 / 94$

$06 / 04 / 94$
Completion

$09 / 26 / 94$

$11 / 03 / 94$

Completion

Date

$09 / 26 / 94$

$11 / 03 / 94$

Tech Spec

Deadline

$11 / 03 / 94$

$09 / 26 / 94$

$11 / 03 / 94$

$09 / 26 / 94$

$11 / 03 / 94$

$09 / 26 / 94$

$11 / 03 / 94$

$10 / 10 / 94$

$09 / 02 / 94$

$09 / 17 / 94$

$10 / 25 / 94$

$06 / 08 / 94$

$09 / 28 / 94$

$06 / 08 / 94$

$09 / 13 / 94$

$01 / 03 / 95$ 
Requirement

TC 291

Low-Low-Low Level Pony Motor Trip Relay Test

JAN/APR/JUL/OCT

TC 324

Review of HFBR

Management Technical

and Rad Safety Support

JAN/APR/JUL/OCT

TC 117

Bldg. Confinement Leak Rate

MAR/SEP

TC 134

Exit Air Bypass Filter Tests

SEP

TC 160

HFBR Main Control Rod AUG

Shutdown Margin Test

$\mathrm{HE} 3 \& 11(\mathrm{~A})$

24 VDC Battery Float

Voltage

MONTHLY

HE $3 \& 11$ (B)

24 VDC Battery Load Test SEP

HP 22

NSS CHI Chamber

Characteristics Curve

MAR/JUN/SEP/DEC

EP 25

NSS CH2 Chamber

Characteristics Curve

MAR/JUN/SEP/DEC

HP 28

NSS CH3 Chamber

Characteristics Curve

$\mathrm{MAR} / \mathrm{JUN} / \mathrm{SEP} / \mathrm{DEC}$

HR $12 \ldots 82(\mathrm{~A})$

Main Rod Reactivity

Measurement

MAR/SEP
Previous

Tech Spec

Period

$3 M$

$3 M$

$6 \mathrm{M}$

A

A

DUE

M

DUE

A

A

DUE

A

DUE

A

DUE

A

DUE

Date

$06 / 07 / 94$

$07 / 11 / 94$

$04 / 16 / 94$

$04 / 21 / 94$

$09 / 04 / 92$

$07 / 29 / 94$

$09 / 10 / 93$

$03 / 03 / 94$

$0.3 / 03 / 94$

Current

Completion

Date

$09 / 12 / 94$

$01 / 02 / 95$

$09 / 30 / 94$

$01 / 20 / 95$

$09 / 25 / 94$

$05 / 07 / 95$

$09 / 29 / 94$

$12 / 29 / 95$

$09 / 03 / 93$

$12 / 03 / 94$

$08 / 31 / 94$

$10 / 08 / 94$

$09 / 12 / 94$

$12 / 12 / 95$

$06 / 14 / 94$

$09 / 14 / 95$

$06 / 16 / 94$

Deadline

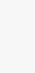

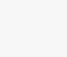


Requirement

HT 67-70

FCF Chambers (RRa-101,

102, 103 and Spare)

Calibration

MAR/JUN/SEP/DEC

HU 54

FIa-301 Calibration

SEP

HO 58

SEP

FI-303 Calibration

HU 331-333

Peak Acceleration

Recorder Calibration

Sep 1994/Mar 1996

HE $3 \& 11$ (D)

24 VDC Battery Discharge Sep 1994

5Y

DUE

M

$250 \mathrm{~V}$ Monthly Battery

Inspection

MONTHLY

TC $632 \mathrm{E}$

Monthly Pony Motor

Battery Inspection

MONTHLY

A

DUE

A

A

$18 \mathrm{M}$

M
Previous

Tech Spec

Period

$09 / 22 / 93$

$09 / 23 / 94$

$12 / 23 / 95$

Date

$03 / 03 / 94$

$06 / 16 / 94$

$09 / 16 / 95$

$09 / 22 / 93$

$09 / 23 / 94$

$12 / 23 / 95$

$11 / 27 / 89$

$05 / 27 / 95$

$04 / 01 / 93$

$09 / 29 / 94$

$07 / 29 / 96$

$08 / 01 / 94$

$09 / 01 / 94$

$10 / 09 / 94$

$08 / 01 / 94$

$09 / 01 / 94$

$10 / 09 / 94$

.. end... 
SUMMARY OF HFBR IRRADIATIONS

09-01-94 TO 09-30-94

NO IRRADIATIONS PERFORMED 